\title{
GEOLOGY
}

UDC 550.4 (574)

V. S. Portnov, Dr. Sc. (Tech.), Prof., orcid.org/0000-0002-4940-3156,

A. N. Kopobayeva, orcid.org/0000-0002-0601-9365,

A. Amangeldikyzy, orcid.org/0000-0002-6665-8804,

N.S. Askarova,

orcid.org/0000-0002-2103-6198 https://doi.org/10.29202/nvngu/2019-6/1

Karaganda State Technical University, Karaganda, the Republic of Kazakhstan, e-mail: aiman_25.87@mail.ru

\section{PATTERNS OF BERYLLIUM DISTRIBUTION IN ROCKS OF CENTRAL KAZAKHSTAN}

Purpose. To establish patterns of beryllium distribution in rocks to identify geochemically specialized rocks in order to improve the effectiveness of regional forecasting aimed at expanding the rare metal base of the country.

Methodology. It is based on systematic and mathematical analyses. The basis of the work laid on the system of regional clarkes of Central Kazakhstan, based on these data correlation graphs of interrelations of an element with oxides of various elements in rocks are constructed, by means of which features of Geochemistry of beryllium in geological formations are revealed.

Findings. On the basis of the analysis of distribution and established correlations of beryllium in rocks of Central Kazakhstan the geochemical regularities of its distribution in different types of rocks are determined and geochemically specialized rocks in relation to this element are revealed. The patterns of beryllium distribution and factors influencing its distribution in rocks of Central Kazakhstan are revealed. It is established that the terrigenous and metamorphic rocks with the highest content of $\mathrm{SiO}_{2}$ and $\mathrm{K}_{2} \mathrm{O}$ have higher average contents of Be compared to chemogenic ones. This indicates that the terrigenous rocks of the studied region are products of mechanical destruction of previously formed igneous rocks, and metamorphic rocks were formed by regional isochemical metamorphism. All the patterns characteristic of igneous rocks of Central Kazakhstan are characteristic of the products of their destruction and isochemical changes as well, which is determined by their geological position, namely, confined to the zones of erosion and destruction of the original rocks of geosynclines and spatial relationship with igneous rocks.

Originality. For the first time an analysis of the distribution of Be in the rocks of Central Kazakhstan was carried out on the basis of the developed system of regional clarkes and the laws of its distribution were established; for Be geochemically specialized and potentially ore bearing rocks were identified. The regularities of beryllium distribution, typical for different genetic types of rocks, testifying to the processes of destruction of parent rocks and accumulation of sedimentary rocks in geosynclinal structures are also determined.

Practical value. Consists in the fact that in the general system chain of metallogenic forecasting and searches, the established data on the geochemical specialization of geological formations in relation to beryllium will allow the formational interpretation of anomalous geochemical fields detected during the multi-purpose geological and geochemical mapping; zoning of the studied areas by types of geological formations possessing one or another potential ore content with the release of the most productive subformations; giving quantitative estimates of forecast resources.

Keywords: geochemistry, beryllium, igneous rocks, sedimentary rocks, metamorphic rocks, Central Kazakhstan

Introduction. Beryllium is a unique, rare, and strategically important metal. It increases corrosion resistance and is used as an alloying element to improve the properties of metals. Due to its physical properties, beryllium is widely used in aviation, rocket, space and energy infrastructure, which entails the growth of demand for beryllium on the global market. The growth in electronics consumption has led to a significant increase in the demand for beryllium on the world market. This element is considered as a strategic metal for the CIS countries and the EU [1]. The USA is a leader in the global beryllium market with over $87 \%$ of the world's metal production followed by China, Mozambique, Brazil and Madagascar.

Consumption of beryllium in the world is already ahead of supply. Kazakhstan has several large beryllium deposits. Stable

(C) Portnov V. S., Kopobayeva A. N., Amangeldikyzy A., Askarova N. S., 2019 operation of the country's industry requires expanding raremetal reserves. In this regard, there is an emerging scientific interest to the geochemistry and metallogeny of beryllium. Reliable data on the distribution of the element in the rocks of Central Kazakhstan enable to study the patterns of distribution of beryllium, which falls within the rare metal group. In Central Kazakhstan, there are about one hundred beryllium deposits, including deposits with unique reserves. Clarke of beryllium in the earth's crust varies from 1.5 to $3.8 \mathrm{~g} / \mathrm{t}$.

Central Kazakhstan has necessary geochemical resources and a system of regional rock clarkes for 168 types of rock [2, $3]$. The studied area is one of the most geochemically studied regions of the world. This area boosts a significant number of commercial rare metal deposits: proper tungsten, complex deposits, proper molybdenum, rare-metal, complex deposits. There are two explored beryllium deposits in Kazakhstan, Nurataldy in Central Kazakhstan (beryl) and Karazhal in 
Chingiz (gelvin, chrysoberyl). In small objects, beryllium is recorded as a co-component in molybdenum-tungsten and tantalum deposits. Therefore, the search for new commercially significant deposits in beryllium is highly relevant. Due to systematic analysis of data on the geochemistry of beryllium and existing system of regional rock clarkes and clarkes of the earth's crust, a number of results have been achieved. Geochemically specialized beryllium-containing rocks have been identified which are the most important tool in geochemical forecasts and prospecting. In the general flow of metallogenic forecasting and prospecting, the found data on the geochemistry of geologic formations with respect to Be will facilitate formational interpretation of abnormal geochemical fields discovered during multi-purpose geological and geochemical mapping. It will also enable to classify the studied territories according to the types of geological formations having particular potential mineralization with identification of the most productive subformations, as well as to quantify estimated resources.

Clarkes of Beryllium shown below in igneous, sedimentary, and metamorphic rocks of large folded polycyclic region of Central Kazakhstan will significantly add to the geochemistry of this element in these types of rocks and processes that affect the distribution patterns.

Geological position of Central Kazakhstan in global structures. The Central Kazakhstan region today is a mosaic structurally complex mega-sheet folded structure in the western part of the Ural-Mongolian folded belt, referred to in modern literature $[4,5]$ as the Central Asian orogenic belt. It is located between East European, Siberian, Tarim and North Chinese cratons [4-6], one of the longest and most complex mobile zones of the Earth, which combines large tectonic blocks of microcontinents (Kokshetau, Ulytau, Aktau-Zhongarsky and others) and fragments of tectonic plates [7], composed of geological formations of various geotectonic situations framed by Lower Paleozoic volcanogenic, siliceous and flysch complexes. As for the structure of microcontinents, it is formed by the Precambrian metamorphic basement (composed of amphibolites, ortho-crystalline schists, eclogites, quartzites, metabasalts, paracrystalline schists, etc.) and a complex deformed cover $[8,9]$. According to the time of the formation of the mature continental crust, it falls within the Caledonian and Hercynian tectogenesis as per Fig. 1. The rocks of the region are AR-J igneous, sedimentary, and metamorphic rock.

Igneous rocks of Central Kazakhstan are found practically throughout the entire territory and are associated with orogenic processes and tectono-magnetic activization. The basic part of sandy rocks of Central Kazakhstan is distributed in ophiolite and arc complexes (Early Caledonian, Devonian, Late Paleozoic volcanic plutonic belts). Carbonaceous rocks of Central Kazakhstan are confined to the riftogenic structures of the Hercynian zones of tectonic-magmatic activization. Similarly to other regions of the world, siliceous rocks are located in Central Kazakhstan mainly among the Lower Paleozoic sediments of the Caledonian geosynclines. Siltstones and mudstones are confined to epiproterozoic and epipaleozoic platforms and quasi-platforms.

Patterns of beryllium distribution. In the igneous rocks of Central Kazakhstan, the concentration of beryllium is associated with acid and ultra-acid rocks, including alkaline and subalkaline granitoids (Table, Fig. 2). It was found that with increasing silicic acidity of rocks the correlation between the beryllium and fluorine contents in the igneous rocks of Central Kazakhstan increases, as well as there is a direct proportional relation between the beryllium contents and the $\mathrm{SiO}_{2}$ value (Fig. 3). To plot the graphs in Fig. 3, rocks that have Be clarke in rocks higher than the clarke of the earth's crust are excluded from the general ranking (as a rule, they are considered geochemically specialized): alkaline, subalkaline rocks (clarke No. 4, 40, 41, 9, 60, 61) and ultra-acidic plutonic leucogranites (clarke No. 54, 53, 62, 63, 65, 64, 67).
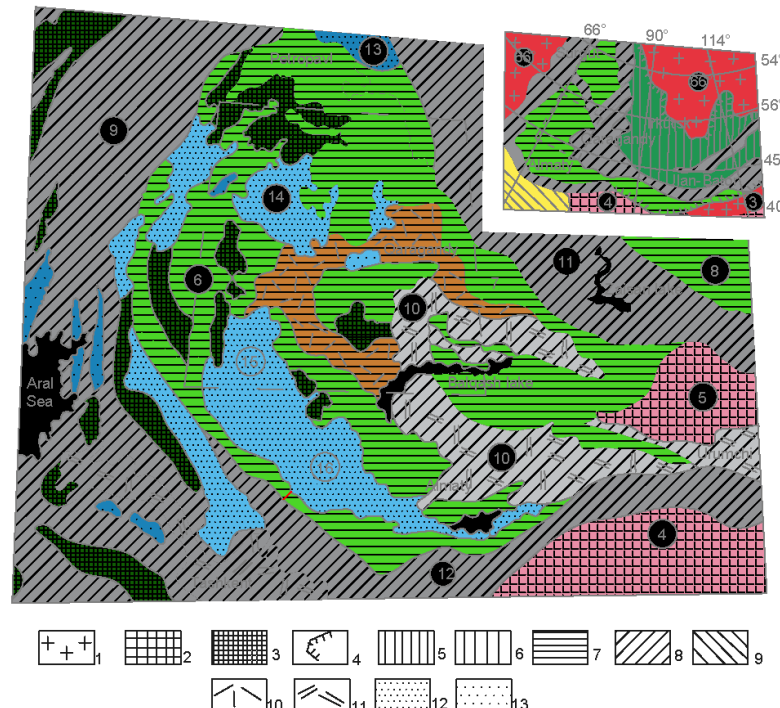

Fig. 1. Tectonic position of Central Kazakhstan in global structures by (Glukhan, Serykh, 1996):

1 - Early Precambrian platforms, 2 - Post-Karelian platform massifs, 3 - Precambrian massifs processed by Paleozoic tectonic movements. 4-8 - Ural-Mongolian folded belt structures: 4-belt borders, 5 - Baikalids, 6-Salairides, 7-Caledonides, 8- Hercinids. 9-Alpides. 10-11-volcanic-plutonic belts: 10-Central Kazakhstan (Devonian), 11 - Balkhash-Ili (Late Paleozoic). 12 - superimposed synclines on the folded Caledonian basement, 13 - superimposed Hercynian synclines. Numbers on the map: 1-3-platforms: 1 - East European, 2 - Siberian, 3 - KoreanChinese. 4-5 - platform massifs: 4 - Tarimsky, 5-Zhungarsky. 6-8-Caledonian folded belts: 6 - Kokchetav-North-Tien Shan, 7-Chingiz, 8-Altai-Sayan. 9-12-Hercynian folded belts: 9 Ural, 10 - Zhungar-Balkhash, 11 - Irtysh-Zaysan, 12 - South Tien Shan. 13-16-depressions: 13 - Tobolsk, 14 - Teniz, 15 Zhezkazgan, 16 - Chu

Analysis of the patterns suggests that the beryllium content naturally increases in alkaline rocks of Central Kazakhstan with an increase in $\mathrm{Al}_{2} \mathrm{O}_{3}$. There is a clear correlation between $\mathrm{Be}$ and $\mathrm{Al}_{2} \mathrm{O}_{3}$ ranging from 4 to 21 (Fig. 4), characterized by statistics $R=0.92 ; S= \pm 0.8 \mathrm{~g} / \mathrm{t}$ with the equation: $y=0.112 x^{1.36}$. It was established that during crystallization of granitoids, beryllium follows silicon, and in alkaline formations it follows after aluminum and its clear correlation dependence is higher in alkaline rocks than in granitoids.

Studies on the patterns of Be abundance in sedimentary rocks of Central Kazakhstan found that elements are grouped into three distribution regions (Fig. 5): $I$ - limestone, dolomite, dolomitic limestone, calcareous dolomite, siliceous limestone, silty limestone, silty dolomite; III - jasper, clay jasper, phthanite, clay phthanite, flint, clay flint, tuff silicite low, although it has a trend of growth from limestone $(0.3 \mathrm{~g} / \mathrm{t})$ to silty limestone $(0.6 \mathrm{~g} / \mathrm{t})$ in the first cloud and a trend of decrease from clay phthanite $(0.9 \mathrm{~g} / \mathrm{t})$ to jasper $(0.5 \mathrm{~g} / \mathrm{t})$ in the third cloud, which is explained by the absence of carrier minerals or beryllium concentrators. Also, two terrigenous rocks, quartz sandstone and oligomesomictic, fall within the third cloud as chemogenic sediments with high silicon content (84.89-91.99\%). In the second cloud where the Be content is increased, terrigenous sediments are observed which show an increase in the average Be content with an increase in the potassium content. This suggests that terrigenous rocks are the products of mechanical destruction of the previously formed igneous rocks of the region. Moreover, all their characteristic patterns stay in their alteration product, in particular in lithoclastic greywackes, siltstones, and mudstones.

By the nature of beryllium distribution in metamorphic rocks of Central Kazakhstan, two groups can be distinguished: 
Regional clarkes of Be in igneous rocks of Central Kazakhstan by [2]

\begin{tabular}{|c|c|c|c|c|c|c|c|c|}
\hline Igneous rock & \multicolumn{4}{|c|}{ No. of clarke } & \multicolumn{4}{|c|}{$\mathrm{SiO}_{2}, \%$} \\
\hline \multirow[t]{4}{*}{ Ultrabasic } & \multicolumn{4}{|c|}{32} & \multicolumn{4}{|c|}{39.86} \\
\hline & \multicolumn{4}{|c|}{33} & \multicolumn{4}{|c|}{40.16} \\
\hline & \multicolumn{4}{|c|}{31} & \multicolumn{4}{|c|}{41.68} \\
\hline & No. of clarke & $\mathrm{SiO}_{2,} \%$ & No. of clarke & $\mathrm{SiO}_{2,} \%$ & No. of clarke & $\mathrm{SiO}_{2,} \%$ & No. of clarke & $\mathrm{SiO}_{2}, \%$ \\
\hline \multirow[t]{2}{*}{ Basic } & 35 & 44.10 & 37 & 48.25 & 1 & 49.67 & 3 & 50.01 \\
\hline & 34 & 46.19 & 36 & 49.26 & 2 & 50.44 & 4 & 53.59 \\
\hline \multirow[t]{5}{*}{ Middle } & 40 & 54.38 & 6 & 55.45 & 10 & 60.27 & 12 & 61.12 \\
\hline & 41 & 54.59 & 39 & 55.48 & 13 & 60.35 & 14 & 61.30 \\
\hline & 8 & 54.81 & 7 & 55.49 & 44 & 60.80 & 45 & 61.34 \\
\hline & 38 & 55.29 & 9 & 56.16 & 42 & 60.86 & 43 & 61.68 \\
\hline & 5 & 55.31 & 11 & 60.17 & 46 & 60.85 & - & - \\
\hline \multirow[t]{7}{*}{ Acid } & 17 & 65.06 & 48 & 65.83 & 58 & 70.21 & 20 & 70.93 \\
\hline & 16 & 65.23 & 49 & 65.83 & 24 & 70.34 & 21 & 70.94 \\
\hline & 47 & 65.47 & 51 & 66.00 & 23 & 70.42 & 60 & 70.97 \\
\hline & 15 & 65.49 & 18 & 66.06 & 25 & 70.44 & 61 & 71.06 \\
\hline & 19 & 65.64 & 52 & 66.53 & 56 & 70.54 & 59 & 71.58 \\
\hline & 54 & 65.72 & 53 & 65.99 & 57 & 70.89 & - & - \\
\hline & 50 & 65.81 & 55 & 70.14 & 22 & 70.93 & - & - \\
\hline \multirow[t]{3}{*}{ Ultra-acid } & 62 & 73.94 & 63 & 75.20 & 64 & 75.55 & 30 & 75.70 \\
\hline & 26 & 74.47 & 28 & 75.34 & 67 & 75.55 & 27 & 75.88 \\
\hline & 29 & 74.81 & 65 & 75.54 & 66 & 75.69 & - & - \\
\hline
\end{tabular}

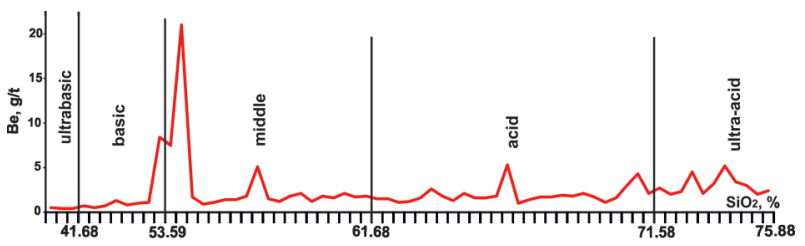

Fig. 2. Graph of Be distribution in igneous rocks depending on the $\mathrm{SiO}_{2}$ content
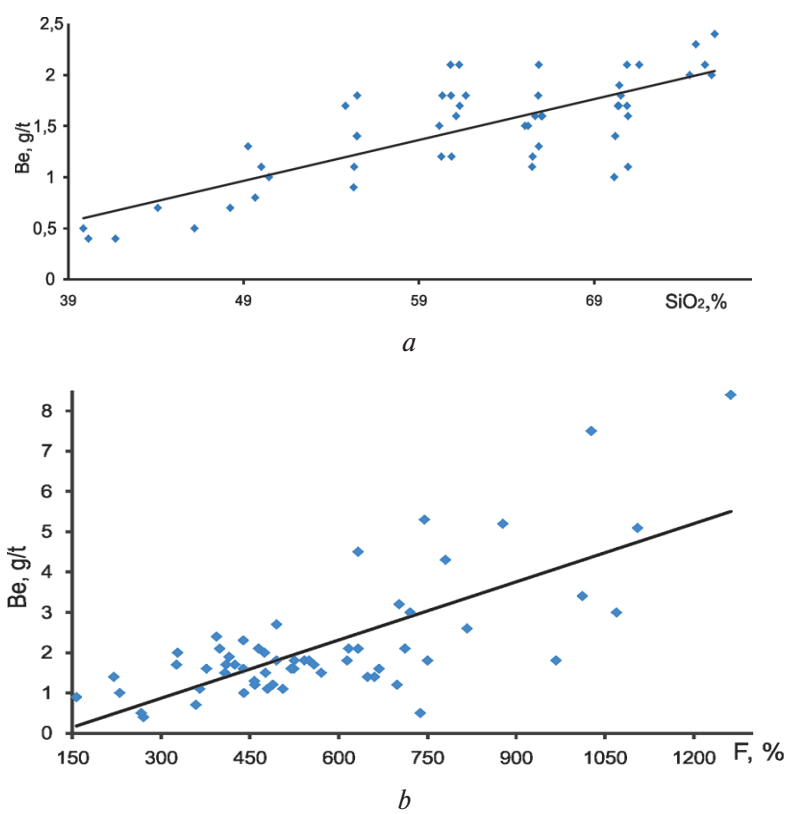

Fig. 3. Graphs of Be distribution in igneous rocks depending on the $\mathrm{SiO}_{2}(a)$ and $F(b)$ content a uniform distribution (graph $I$ ) and a distribution with an extremum in the range of $\mathrm{SiO}_{2}$ content from 70 to $75 \%$ (Fig. 6).

Analysis of the patterns of Be distribution in metamorphic rocks showed that if the element content is low in ultrabasic and basic igneous rocks, there is accordingly no increased $\mathrm{Be}$ content in ultrabasic and basic metaplutonic and metavolcanic rocks (clarkes No. 155, 156, 161, 163, 164 according to [2, $3]$ ). An increased content of Be is observed in potassium metasedimentary rocks (clarkes No. 147, 148, 150, 152) and metavolcanic rock types (clarkes No. 159, 160). If a rock has high silicon content with low potassium content, the Be content in it will be lower (metaplagiogranite, clarke No. 165, was formed during the alteration of a mother rock of plagiogranite $(\mathrm{Na}$ granite) with average Be content $0.8 \mathrm{~g} / \mathrm{t}$ ). In rapakivi-like metagranites, metaleukogranites, and meta-alaskites with increasing silicon the Be content increases (clarkes No. 166, 167, 168 respectively) as shown in Fig. 6.

The main feature of distribution of $\mathrm{Be}$ in the rocks of Central Kazakhstan is that sedimentary and metamorphic rocks

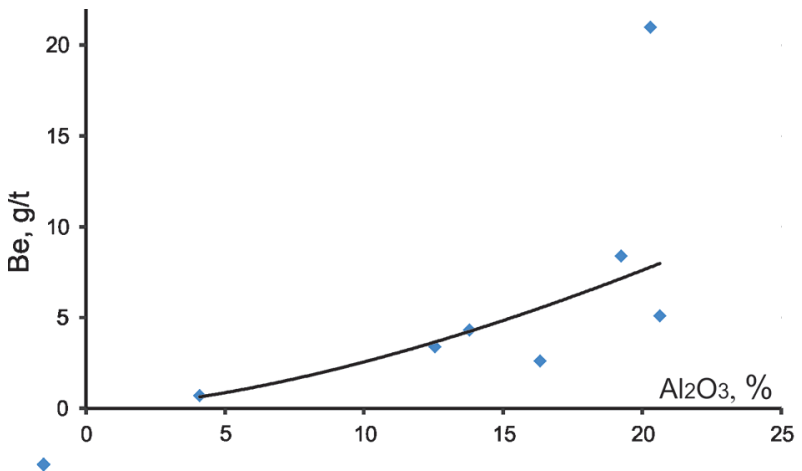

Fig. 4. Graph of Be distribution in alkaline rocks depending on the $\mathrm{Al}_{2} \mathrm{O}_{3}$ content 


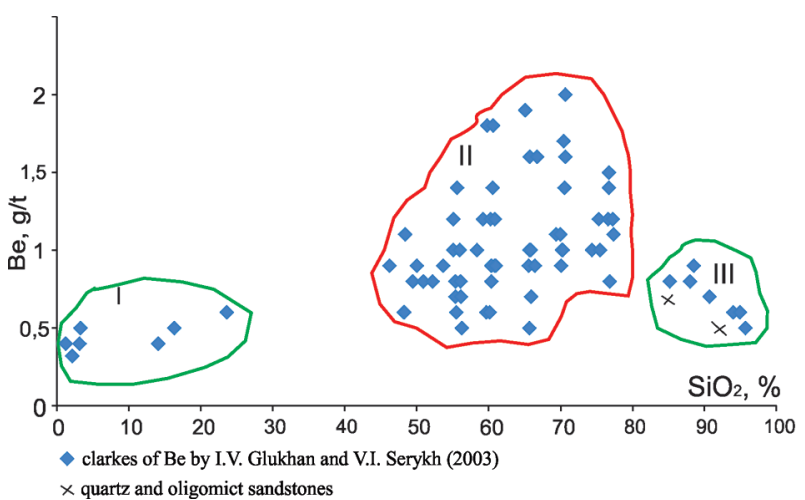

Fig. 5. Correlation field of the distribution of $\mathrm{Be}$ and $\mathrm{SiO}_{2}$ in sedimentary rocks

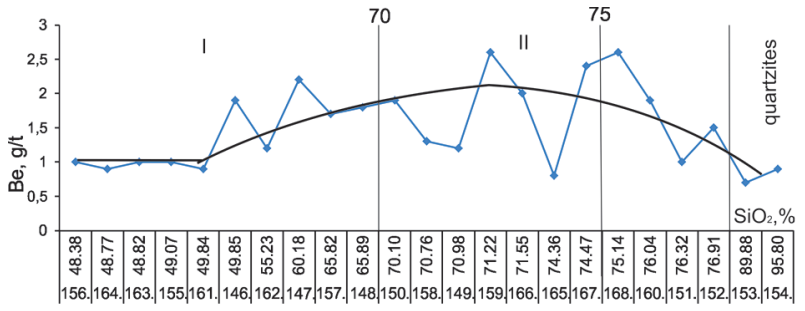

Fig. 6. Graph of $\mathrm{Be}$ distribution in metamorphic rocks depending on the $\mathrm{SiO}_{2}$ content

have the same distribution patterns that are characteristic for igneous rocks. They have correlation dependences of $\mathrm{Be}$ and $\mathrm{SiO}_{2}$ (Figs. 3, $a, 7$ ), as well as of $\mathrm{Be}$ and $\mathrm{K}_{2} \mathrm{O}$ at $R=0.74$ for igneous rocks, $R=0.84$ for sedimentary, $R=0.92$ for metamorphic rocks (Fig. 8).

All the established patterns of Be distribution in the rocks of Central Kazakhstan indicate the proximity of the compositions of these rocks and testify that when the geosynclines were eroded, the base rocks were not subjected to strong alterations, and the same composition was preserved during regional isochemical metamorphism. Significant similarity of the composition of mother rocks and source area rocks in geosynclines
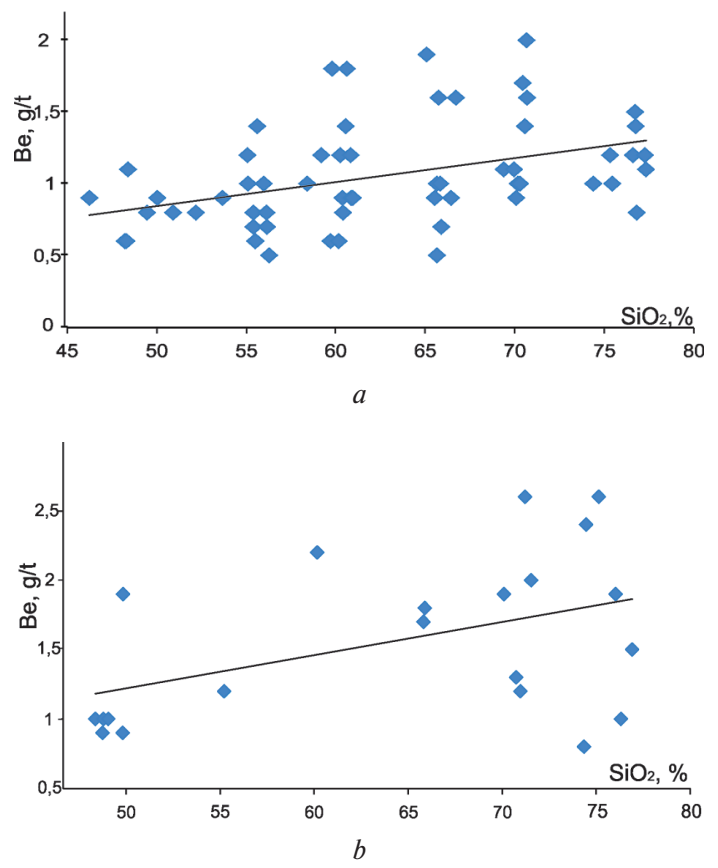

Fig. 7. Graphs of Be distribution in sedimentary (terrigenous) (a) and metamorphic (b) rocks depending on $\mathrm{SiO}_{2}$ content under different geodynamic conditions was noticed earlier by researchers in [9-11]. According to the authors, this is due to erosion of the base rocks and translation into sedimentary rocks without significant fractionation while preserving the parameters of the source rocks, which is also confirmed by the results of our study.

Conclusions. There has been determined general pattern of an increase in Be content in all types of rocks of Central Kazakhstan depending upon $\mathrm{SiO}_{2}$ content. For igneous rocks of Central Kazakhstan, a correlation dependence between Be and $\mathrm{F}$ was established, as well as the fact that beryllium content and the amount of $\mathrm{SiO}_{2}$ are in a direct proportional relation. There is an increased content of Be in alkaline rocks, which is explained by the correlation between beryllium and aluminum described by the equation: $y=0.112 x^{1.36}$. It is proved that the main feature of the pattern of Be distribution in the rocks of Central Kazakhstan is the similarity of patterns of distribution in both sedimentary/metamorphic and igneous rocks. Correlation dependences of $\mathrm{Be}$ and $\mathrm{SiO}_{2}$ are observed in them with a correlation coefficient of $R=0.4$ and $R=0.45$ respectively, despite the fact that in igneous rocks this coefficient $R=0.77$, as well as $\mathrm{Be}$ and $\mathrm{K}_{2} \mathrm{O}$ at $R=0.74$ for igneous rocks, $R=0.84$ for sedimentary rocks, $R=0.92$ for metamorphic rocks. All potassium varieties of rocks of the studied region have higher beryllium grades as compared to sodium and $\mathrm{K}$-sodium varieties of the same types of rocks.

This indicates that in the territory of Central Kazakhstan during the erosion of mother rocks in geosynclinal regions and systems under various geodynamic conditions terrigenous rocks were formed out of them, whereas regional metamorphism occurred isochemically, i.e. without chemical alteration in the source rocks. These data can be helpful for reconstructing the exogenous processes of formation of sedimentary rocks and deposits since they can provide information on the sources and mechanism of ablation of the base material and
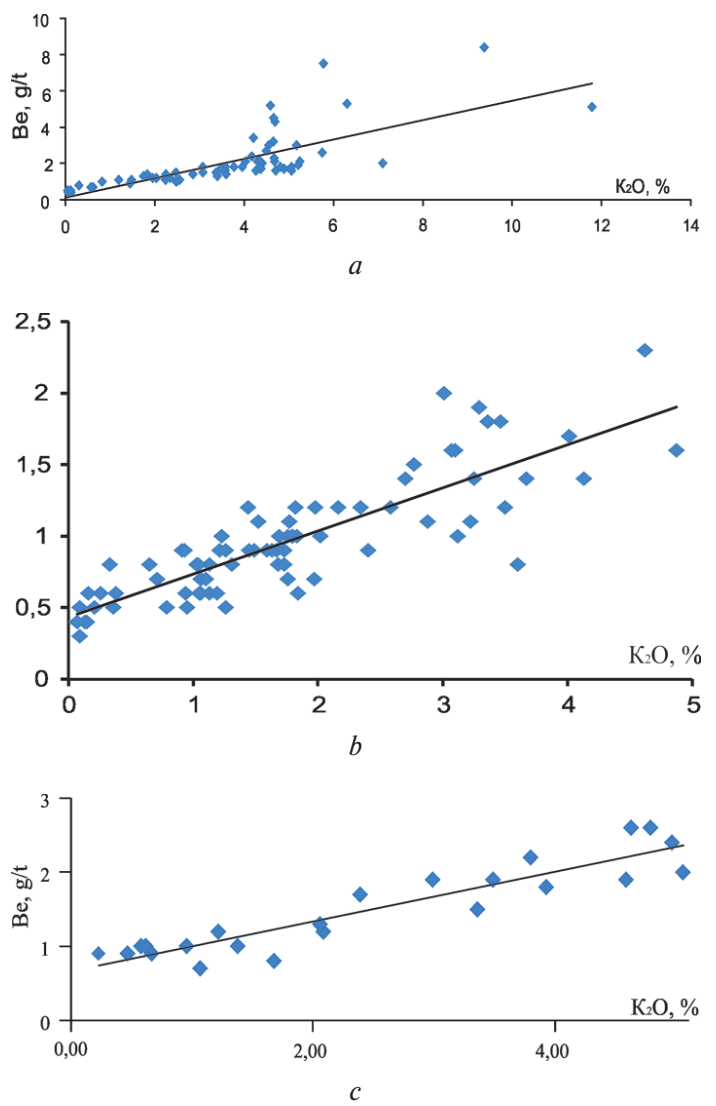

Fig. 8. Graphs of the distribution of $\mathrm{Be}$ in rocks depending on the $\mathrm{K}_{2} \mathrm{O}$ content:

$a$-igneous; $b$ - sedimentary; $c$ - metamorphic 
the concentration of rare and rare-earth elements in sedimentary rocks, in particular mudstones and sandstones. During the study on the distribution of beryllium in the rocks of Central Kazakhstan, some geochemical characteristics related to factors that determine geochemical specialization of the rocks were revealed. In particular, chemical composition of the source rocks is most important parameter in controlling the formation of sedimentary and metamorphic rocks. In turn, composition of the rocks directly depends on the geotectonic processes and the geodynamic setting. For example, weathering conditions affect geochemistry of sedimentary rocks. Significant changes in the chemistry of rocks can occur during the transfer of sedimentary particles, which lead to the accumulation of elements in clay constituents. At the same time, in Central Kazakhstan, just like in many other geosyncline zones of the world, there are a significant number of coal deposits where coals, host rocks, as well as interlayers (tonshteins) also contain rare, rare-earth and noble elements.

There have been defined geochemically specialized rocks, including potentially Berillium ore bearing rock: subalkaline potassium quartz syenites, alkaline quartz syenites $\mathrm{K}-\mathrm{Na}$, subgranites, leucogranites, alkaline-feldspar leucogranites, leucogranite alaskites, alkaline alaskites.

It is recommended to use regional clarkes of Be for forecasting and prospecting purposes in the territory of Central Kazakhstan since the established patterns of its distribution confirm the feasibility of their use, showing all the features of chemistry, magmatism, sedimentation and metamorphism of the studied region.

\section{References.}

1. Simons, B., Andersen, J., Shail, R., \& Jenner, F. (2017). Fractionation of $\mathrm{Li}, \mathrm{Be}, \mathrm{Ga}, \mathrm{Nb}, \mathrm{Ta}, \mathrm{In}, \mathrm{Sn}, \mathrm{Sb}, \mathrm{W}$ and $\mathrm{Bi}$ in the peraluminous Early Permian Variscan granites of the Cornubian Batholith: Precursor processes to magmatic-hydrothermal mineralization. Lithos, 491-512. https://doi. org/10.1016/i.lithos.2017.02.007.

2. Glukhan, G. V., \& Serykh, V. I. (2003). Clarks of rocks Central Kazakhstan. News of the Nat. Ac. of Sc. of the Rep. of Kazakh, (3), 81-116.

3. Glukhan, I. V., \& Serykh, V.I. (2002). Average concentrations of elements in metamorphic rocks on Central Kazakhstan. Geokhimiya Internat., 40(2), 142-156.

4. Li, M.G., Cao, M., Qin, K., Evans, N. J., Hollings, P., \& Seitmuratova, E.Yu. (2016). Geochronology, petrogenesis and tectonic settings of pre- and syn-ore granites from the W-Mo deposits (East Kounrad, Zhanet and Akshatau) Central Kazakhstan. Lithos, (252-253), 16-31. https://doi.org/10.1016/j. lithos.2016.01.023.

5. Li, P., Sun, M., Gideon, R., Yuan, C., Safonova, I., Cai, K., Jiang, Y., \& Zhang, Yu. (2018). Geometry, kinematics and tectonic models of the Kazakhstan Orocline, Central Asian Orogenic Belt. Journal of Asian Earth Sc, 153, 42-56. https:// doi.org/10.1016/i.jseaes.2017.07.029.

6. He, Zh., Klemd, R., Yan, L., \& Zhang, Z. (2018).The origin and crustal evolution of microcontinents in the Beishan orogen of the southern Central Asian Orogenic Belt. Earth-Science Reviews, 185, 1-14. https://doi.org/10.1016/j.earscirev.2018.05.012. 7. Zhu, X., Wang, B., Cluzel, D., He, Zh., \& Zhong, L. (2019). Early Neoproterozoic gneissic granitoids in the southern Yili Block (NW China): Constraints on microcontinent provenance and assembly in the SW Central Asian Orogenic Belt. Precambrian Research, 325, 111-131. https://doi. org/10.1016/j.precamres.2019.02.019.

8. Degtyarev, K. (2011).Tectonic evolution of Early Paleozoic Island-arc systems and continental crust formation in the Caledonides of Kazakhstan and the North Tien Shan. Geotectonics, 45, 23-50. https://doi.org/10.1134/S0016852111010031. 9. Zurbriggen, R. (2015). Ordovician orogeny in the Alps: a reappraisal. International Journal of Earth Sciences, 104(2), 335-350. https://doi.org/10.1007/s00531-014-1090-x.
10. Maslov, A. V., Mizens, G.A., Podkovyrov, V. N., Nozhkin, A.D., Sokur, T. M., Malinovskii, A. I., ... \& Letnikova, E. F. (2015). Synorogenic Clay Rocks: Specifics of Bulk Composition and Paleotectonics. Geochemistry International, 53(6), 510-533. https://doi.org/10.1134/S0016702915060075. 11. Pokalyuk, V. V., \& Sukach, V. V. (2015). Lithochemistry of metaclastogenic sediments of the Upper Paleoproterozoic of the Kryvoyrog iron ore basin in terms of paleogeographic and paleotectonic formation conditions. Naukovyi Visnyk Natsionalnoho Hirnychoho Universytetu, (2), 14-23.

\section{Закономірності розподілу берилію в породах Центрального Казахстану}

\section{В. С. Портнов, А. Н. Копобаєва, А. Амангельдікизи, Н. С. Аскарова}

Карагандинський державний технічний університет, м. Караганда, Республіка Казахстан, е-mail: aiman_25.87@ $\underline{\text { mail.ru }}$

Мета. Встановити закономірності розподілу берилію в породах для виявлення геохімічно спеціалізованих порід з метою підвищення результативності регіональних прогнозних робіт, спрямованих на розширення рідкометальної бази країни.

Методика. Базується на систематичному й математичному аналізах. В основу роботи покладена система регіональних кларків Центрального Казахстану, грунтуючись на цих даних - побудовані кореляційні графіки взаємозв'язків елемента з іншими оксидами в породах, за допомогою яких виявлені особливості геохімії берилію в геологічних формаціях.

Результати. На основі аналізу розподілу та встановлених кореляційних зв'язків берилію в породах Центрального Казахстану визначені геохімічні закономірності його розподілу в різних типах порід і виявлені геохімічно спеціалізовані породи у відношенні даного елемента. Виявлені фактори, що впливають на його розподіл у породах Центрального Казахстану. Встановлено, що теригенні й метаморфічні породи з найбільшими вмістами $\mathrm{SiO}_{2} \mathrm{i}$ $\mathrm{K}_{2} \mathrm{O}$ мають підвищенні середні вмісти Ве в порівнянні 3 хемогенними. Це свідчить про те, що теригенні породи досліджуваного регіону є продуктами механічного руйнування раніше утворених магматичних гірських порід, а метаморфічні породи утворилися при регіональному ізохімічному метаморфізмі. Усі закономірності, характерні для магматичних порід Центрального Казахстану, характерні й для продуктів їх руйнування та ізохімічної зміни, що визначається їх геологічним положенням, а саме приуроченістю до зон розмиву й руйнування вихідних порід геосинкліналей і просторовим зв'язком із магматичними породами.

Наукова новизна. Уперше проведено аналіз розподілу Ве в породах Центрального Казахстану на основі розробленої системи регіональних кларків і встановлені закономірності його розподілу; виявлені геохімічно спеціалізовані й потенційно рудоносні породи щодо Ве. Також визначені закономірності розподілу берилію, характерні для різних генетичних типів порід, що свідчать про процеси руйнування материнських порід і накопиченні осадових порід у геосинклінальних структурах.

Практична значимість. Полягає в тому, що в загальному системному ланцюжку операцій металогенічного прогнозу й пошуків встановлені дані про геохімічну спеціалізацію геологічних формацій щодо берилію дозволять проводити формаційну інтерпретацію виявлених у ході багатоцільового геологічного й геохімічного картування аномальних геохімічних полів; здійснювати районування досліджуваних територій за типами геологічних формацій, що володіють тією чи іншою потенційної ру- 
доносністю $з$ виділенням найбільш продуктивних субформацій; давати кількісні оцінки прогнозних ресурсів.

Ключові слова: геохімія, берилій, магматичні породи, осадові породи, метаморфічні породи, Центральний Казахстан

\section{Закономерности распределения бериллия в породах Центрального Казахстана}

\section{В. С. Портнов, А. Н. Копобаева, А. Амангельдикызы, Н. С. Аскарова}

Карагандинский государственный технический университет, г. Караганда, Республика Казахстан, e-mail: aiman_25.87@mail.ru

Цель. Установить закономерности распределения бериллия в породах для выявления геохимически специализированных пород с целью повышения результативности региональных прогнозных работ, направленных на расширение редкометалльной базы страны.

Методика. Базируется на систематическом и математическом анализах. В основу работы положена система региональных кларков Центрального Казахстана, основываясь на этих данных - построены корреляционные графики взаимосвязей элемента с другими оксидами в породах, с помощью которых выявлены особенности геохимии бериллия в геологических формациях.

Результаты. На основе анализа распределения и установленных корреляционных связей Ве в породах Центрального Казахстана определены геохимические закономерности поведения бериллия в различных типах пород и выявлены геохимически специализированные породы в отношении данного элемента. Выявлены особенности закономерного распределения Ве и факторы, влияющие на его распределения в породах Центрального Казахстана. Установлено, что терригенные и метаморфические породы с наибольшими содержаниями $\mathrm{SiO}_{2}$ и $\mathrm{K}_{2} \mathrm{O}$ имеют повышенные средние содержания $\mathrm{Be}$, также как и магматические породы по сравнению с хемогенными. Это свидетельствует о том, что терригенные породы изучаемого региона являются продуктами механического разрушения ранее образовавшихся магматических горных пород, а метаморфические породы образовались при региональном изохимическом метаморфизме. Все закономерности, характерные для магматических пород Центрального Казахстана, характерны и для продуктов их разрушения и изохимического изменения, что определяется их геологическим положением, а именно приуроченностью к зонам размыва и разрушения исходных пород геосинклиналей и пространственной связью с магматическими породами.

Научная новизна. Впервые проведен анализ распределения Ве в породах Центрального Казахстана на основе разработанной системы региональных кларков и установлены закономерности его распределения; выявлены геохимически специализированные и потенциально рудоносные породы в отношении Ве. Также определены закономерности распределения бериллия, характерные для разных генетических типов пород, свидетельствующие о процессах разрушения материнских пород и накопления осадочных пород в геосинклинальных структурах.

Практическая значимость. Заключается в том, что в общей системной цепочке операций металлогенического прогноза и поисков установленные данные о геохимической специализации геологических формаций в отношении бериллия позволят производить формационную интерпретацию обнаруженных в ходе многоцелевого геологического и геохимического картирования аномальных геохимических полей; производить районирование исследуемых территорий по типам геологических формаций, обладающих той или иной потенциальной рудоносностью с выделением наиболее продуктивных субформаций; давать количественные оценки прогнозных ресурсов.

Ключевые слова: геохимия, бериллий, магматические породы, осадочные породы, метаморфические породы, Центральный Казахстан

Recommended for publication by A. D. Mausymbayeva. The manuscript was submitted 15.02.19. 